\title{
Correlation between Co-Curricular Activities and Academic Achievement of Students
}

\author{
Dr. Ayesha Batool \\ Lecturer Institute of Education and Research, University of the Punjab, Lahore Pakistan \\ Saghir Ahmad \\ PhD Scholar, Institute of Education and Research, University of the Punjab, Lahore Pakistan
}

\begin{abstract}
Student interest in co-curricular exercises makes positive school associations through expanded his commitment outside of the study atmosphere. A couple of instances of exercises outside the school may incorporate professional social exercises. Co-curricular activities furnish students with development openings that manage authority, working with others, and scholastic goals. The descriptive research was conducted for this purpose. The study was correlation in nature. The population of the study was all the college students, both male and females of government and private sector of district Lahore. The tool that designed to collect data was a questionnaire that constructed on likert scale. There is a moderate positive relationship between participation in co-curricular activities and academic achievement of the students. It is concluded that co-curricular activities play a major role in the academic achievement of the students at college level. The students who actively participate in co-curricular activities have higher percentages than those students who do not participate.
\end{abstract}

Keywords: co-curricular activities, commitment, and academic achievement.

DOI: $10.7176 / \mathrm{JEP} / 11-1-03$

Publication date: January $31^{\text {st }} 2020$

\section{Introduction}

A co-curricular movement is characterized as a program or out-of-class action, managed and financed by the school, which gives educational plan related learning and character building encounters. Co-curricular exercises are willful or not a piece of the standard school educational plan, are not managed and do not acquire credits. It incorporates the games, discusses, tests, shows, craftsmanship exercises, student clubs, affiliations, and associations that direct those exercises. It is also known as co-curricular exercises that instructive association in some piece of the world makes for learners (Pankaj \& Sunil, 2012).

These activities are regularly a way to improve social collaboration, initiative, sound diversion, self-control and self-assurance. At abnormal state of training, CCA support may even interpret scholarly focuses (Ahmed, 2010). A large portion of the old style and practically all cutting edge educationist concede that training is not only the remembrance certain actualities figures and aptitudes however it is all around the improvement of learners. It demonstrates that co-curricular exercises are the indispensable piece of training. Albeit, numerous looks into had been led to investigate the connection between co-curricular exercises with roughly all parts of improvement of students for example physical, social, psychological and moral, however there is no significant research in the field to investigate the connection of co-curricular exercises with scholastic accomplishment of students.

There are various sentiments of what is viewed as a co-curricular action. A couple of instances of exercises outside the school may incorporate professional social exercises, for example, moves, shows, group activities, and performing expressions. Various degrees of action contribution and investment may decidedly affect future accomplishment for the individuals who take an interest. Research likewise shown that both the sort of cocurricular projects (exercises) and level of support may affect the people's improvement (Mossani, 2011). As indicated by Danyal, Tahir, Ali, and Iqra (2012), investment in composed exercises during school is emphatically connected with instructive, community, and somewhat, word related achievement in youthful adulthood. Students should offset their lives with scholastics and exercises as taking part in these balanced exercises may affect their accomplishment later on.

At school and college level on the planet, students have perceived co-curricular courses (George 2012). They who go to co-curricular exercises may adverse effect their participation yet could conceivably on their rates in tests (scholarly accomplishments). There are various ways which can be picked by the learners to invest their free energy and this will influence their scholastics either emphatically or contrarily relying on the action they picked. A study directed by the training branch of United State of America found that the students who effectively contribute in the co-curricular exercises are bound to have more prominent grade point average (GPA) than the individuals who do not partake in these exercises (Schlesser, 2004). This investigation expanded how CCAs influence students' scholastic accomplishments.

It is critical to comprehend the various parts of these exercises. With the goal for learners to feel effective and appreciate association, the action must be founded on student intrigue. Along these lines, with the goal for schools 
to positively affect them with their inclusion in co-curricular exercises, they ought to know about their students intrigue. It is not sufficient for universities to give assets rather, so as to expect the advantages of co-curricular movement investment, they should likewise offer exercises that match student premium and urge them to take an interest in those exercises (Pankaj \& Sunil, 2012).

The researchers who have completed investigation on the co-curricular exercises isolate them into formal and non-formal exercises. The formal exercises are those which incorporate the association of students in games, shows or discussions rivalry and so on. Then again the exercises, for example, listening music or sitting in front of the TV are delegated casual exercises. Study has proposed that both formal and casual exercises affect scholarly execution. One study showed that more you invest energy in relaxation exercises the more unfortunate scholarly execution and more unfortunate working propensities are created while additional time you spend in formal exercises like games, banter and emotional exercises, the more evaluations you get in studies (Marsh \& Kleitman, 2002).

Co-curricular activities furnish students with development openings that manage authority, working with others, and scholastic goals. Intrigued grown-ups lead them, they are organized, they bear the cost of individual development openings, and they give exercises in collaboration. In view of the intentional idea of investment, those learners who pick these exercises do as such dependent on their own personal circumstances. A research has been directed on relational fitness using meetings and school information. These outcomes upheld that these credits added to student accomplishment and long haul scholarly achievement (Schlesser, 2004). Support in co-curricular exercises may prompt improved frames of mind toward college instruction. Students who like school may work more diligently at their scholastic work and be less inclined to leave a setting that they like (Mossani, 2011).

\section{Significance of Study}

Take part in co-curricular exercises results numerous positive results in the scholastic settings. Student interest in co-curricular exercises makes positive school associations through expanded his commitment outside of the study atmosphere. An assemblage of research additionally relates co-curricular cooperation with higher scholastic accomplishment. These exercises additionally help students set up their transcripts and increment open doors for advanced education. Co-curricular exercises likewise help in creating relational and relational abilities. The associations made by taking an interest in co-curricular exercises, enables them to shape associations with coaches both inside the school and in the network.

\section{Research Objectives}

The study was conducted to achieve the following objectives to:

1. Explore relationship between co-curricular activities and academic achievement of the college students.

2. Examine the difference in students' perceptions about co-curricular activities and academic achievement on basis of demographic variables.

\section{Research Methodology}

The descriptive research was conducted for this purpose. The study was correlation in nature. The population of the study was all the college students, both male and females of government and private sector of district Lahore. From the population, three government and three private colleges students were selected as sample of study. Convenient sampling technique was used to select sample. Total 200 respondents had been selected for data collection including boys and girls from all the selected colleges. The data were collected by filling the questionnaire that was developed for this study. The tool that designed to collect data was a questionnaire that constructed on likert scale. The colleges were visited with the permission of the head of the department and the principals of target colleges. Students had been assured that data collected by them will be used only for research purposes. A questionnaire had been constructed to collect data from the sample selected from the college students. Questionnaires were administered by the researchers personally. The response rate for the questionnaire was $100 \%$. A t- test analysis applied to explore the differences in the variables. A Pearson correlation test had been applied to find the correlation coefficient between variables.

Table 1

Instrument Reliability

$\begin{array}{cc}\text { Cronbach's Alpha } & \text { No. of Items } \\ .712 & 25\end{array}$

The value .712 shows very good internal consistency reliability for the scale with this sample. Values above .6 are considered acceptable however above .7 are preferable. So in this case the value .712 is highly acceptable. Total number of items is 25 on which this test has been replied, these includes all the items which makes our scale. 


\section{Data Analysis}

The detail of data analysis is given below.

Table 2

Frequency and percentage of Gender

\begin{tabular}{llllll}
\hline Male & & Female & Mean & SD \\
F & $\%$ & F & $\%$ & & \\
\hline 91 & 45.5 & 108 & 54 & 1.56 & .528 \\
\hline
\end{tabular}

Table shows that there were $45 \%$ percent male respondents and the percentage of female students was $54 \%$ $($ mean $=1.56, \mathrm{SD}=.528)$.

Table 3

Institutions of Respondents

\begin{tabular}{|c|c|c|c|c|c|}
\hline \multicolumn{2}{|c|}{ Government } & \multicolumn{2}{|c|}{ Private } & \multirow[t]{2}{*}{ Mean } & \multirow[t]{2}{*}{ SD } \\
\hline$\underline{F}$ & $\%$ & $\mathrm{~F}$ & $\%$ & & \\
\hline 124 & 62 & 76 & 38 & 1.38 & .487 \\
\hline
\end{tabular}

The above table shows that there were $62 \%$ government colleges and $38 \%$ students were private colleges (mean=1.38, $\mathrm{SD}=.487$ ).

Table 4

Correlation between co-curricular activities and academic achievements of students

\begin{tabular}{lll}
\hline Variables & $r$ & $p$-value \\
\hline Percentage in last exam & .403 & .000
\end{tabular}

Participation in CCAs

The above table shows that there is a moderate positive relationship between participation in co-curricular activities and academic achievement of the students $(r=.403)$. Since the p-value is .000 , i.e. $<.05$, so there is a statistically significant relationship between participation in co-curricular activities and academic achievement.

Table 5

Independent sample t-test to check difference

\begin{tabular}{llllllll}
\hline Variable & Involvement in CCA & $N$ & Mean & $S D$ & $d f$ & $t$ & $P$ \\
\hline Achievement & Yes & 166 & 60.4217 & 9.23054 & 198 & 2.995 & .003 \\
& No & 34 & 55.1176 & 10.24478 & & & \\
\hline
\end{tabular}

An independent-sample t-test is used when you want to compare the mean score, on some continuous variable, for two different groups of subjects. An independent- samples t-test will tell you whether there is a statistically significant difference in the mean scores for two groups. The above table looks into the participation in cocurricular activities of respondents and their academic achievement (percentage in last exam). The sig. value is greater than $0.05(.293)$ hence the upper value $(.003)$ is taken from the line. P-value .003 shows that there is significant difference between the percentages of those students who participate in co-curricular activities and those who do not participate.

\section{Conclusion}

The purpose of this study was to find the relationship between involvement in co- curricular activities and academic achievement of the students at college level. Based on findings it is concluded that co-curricular activities play a major role in the academic achievement of the students at college level. The students who actively participate in co-curricular activities have higher percentages than those students who do not participate. The statistics also show that there is no significant difference in the percentages of the students in the result of the comparison of their institution, e.g. government or private. If we put a glance on the value of co-relation coefficient, it also shows that there is positive relationship between participation in co-curricular activities and academic achievement of the students. It is also witnessed that those students who even got positions in previous classes, also had been involved in co-curricular activities. The majority of the respondents viewed that co-curricular activities did not had negative effects on their grades or attendance. The frequencies show that most of the students choose sports as co-curricular activity. This study explored the relationship between participation in defined co-curricular activities and academic achievement of male and female students in both private and government sector. Previous studies supported findings that indicated involvement in co-curricular activities reflected positive impact on academic achievement. Needleman (2001) found that many co-curricular activities teach real-world skills, such as journalism, photography, or debate, which can lead to lifelong interests, even careers. Most of the studies found that children who participate in these activities are more successful academically than those who do not.

\section{Recommendations}

On the basis of findings, some recommendations made which would be helpful in future.

1. It is exposed that the students who take part actively in co-curricular activities also take benefit in 
their studies. The students, teachers and parents should be aware of the fact that which co-curricular activity is beneficial. Every student performs in the studies at his best while taking part in other positive activities, so one should not expect extra ordinary performance from every student because he or she is also taking part in other positive activities which is not only helpful for the development of his or her health but also it creates balance in his or her personality. However parents should not enforce their children to take part in co-curricular activities to improve their grades. Different students have different likings and intentions. Parents should search out those activities in which their children can participate well according to his or her capabilities.

2. Secondly, parents should also not forbid their children to take part in sports and other co- curricular activities, like debates, concerts, and art activities. The involvement in such activities helps them in number of ways. These activities develop social skills, sportsman spirit, and health as well as class performance.

3. Co-curricular activities serve at a large for the development in the academic, social, mental, and character of students and also co-curricular activities give mentally refreshment and build a confidence in students and every students should be provided with the chance to take part in at least one healthy and positive activity. However the purpose of such activities should be to improve their mental and physical health. Parents should allow their children to choose their co-curricular activity and they should have check on their activities. These are the parents who have the essential role in the development of the character and health of their children. They should provide their children with the best available facilities so that they become able to perform well in both academics and in ground.

\section{References}

Ahmed, F. (2011). The p.o.e.m.s of educational research: A beginners' concise guide. International Education Studies, 4(3), 23-30.

Brown, M. D. (2000). Science or soccer?-How important are extracurricular activities? Education World.

Daniyal, M., Nawaz, T., Hassan, A., \& Mubeen, I. (2012). The effect of co-curricular activities on the academic performances of the students: A case study of the islamia University of Bahawalpur, Pakistan. Bulgarian Journal of Science and Education Policy (BJSEP), 6(2).

Fortune, R. (2013). A study of the effect of co-curricular courses on student attendance, composite act score and student dropout rate. The Department of Professional Education Northwest Missouri State University Missouri

Fredricks, J. A. (2011). Extracurricular participation and academic outcomes: Testing the over- scheduling hypothesis. Journal of Youth and Adolescence, 41, 295-306.

Fredricks, J. A., \& Eccles, J. S. (2010). Breadth of extracurricular participation and adolescent adjustment among African-American and European-American youth. Journal of Research on Adolescence, 20(2), 307-333.

George, S. (2010). The benefits of extracurricular activities in high school: Involvement enhances academic achievement and the way forward. Academic Leadership, 8(3), 1- 9.

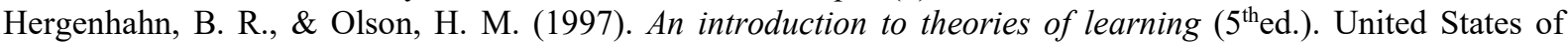
America: Prentice Hall International.

Holloway, J. H. (1999). Extracurricular activities: The path to academic success. Educational Leadership, 57(4), 87-88.

James, S. R. (1994). Socioeconomic status and academic achievement: A meta-analytic review of research. Review of Educational Research, 75(3), 417-453.

Marsh, D., \& Kleithman, B. (2002). The extracurricular advantage. Educational Leadership, 86(1), 86- 87.

Marsh, H. W. (1992). Extracurricular activities: Beneficial extension of the traditional curriculum or subversion of academic goals. Journal of Educational Psychology, 84(4), 553-562.

Massoni, E. (2011). Positive effects of extra-curricular activities on students. ESSAI, 9(27).

Needlman, R. F. (2001). Extracurricular activities. Retrieved from http://www.drspock.com/article/0,1510,html.

Nicoli, J. (2011). Extracurricular school activities and the benefits. Retrieved from http://www.educationworld.com/a_curr/curr237.shtml

North Carolina High School Athletic Association. (2001). The case for high school activities. North Carolina. North Carolina High School Athletic Association.

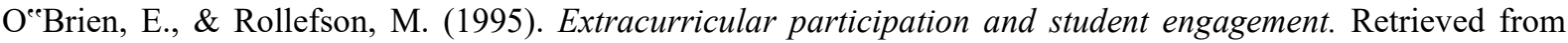
National Center for Education Statistics website:

Pankaj, E., \& Sunil, W. (2012). After the bell: Participation in extracurricular activities, classroom behavior, and academic achievement. American Sociological Association, 83(1), 20-45.

Regina, B. (2011). Linking extracurricular programming to academic achievement: Who benefits and why? Sociology of Education, 75(1), 69-91.

Schlesser, C. (2004). The correlation between extracurricular activities and grade point average of middle school 
students. The Graduate School University of Wisconsin-Stout Menomonie.

Schunk, D. H. (2004). Learning theories. ( $5^{\text {th }}$ ed.). The University of Michigan: Pearson/Merril/Prentice Hall.

Weber, B. (2008). Student involvement in co-curricular activities and success on the kansas mathematics and reading assessments. Graduate Department and Faculty of the School of Education of Baker University.

Wilson, N. (2009). Impact of extracurricular activities on students. University of Wisconsin-Stout. 